\title{
Germination and Initial Development of Carioca Beans Treated with Bio-Stimulant
}

\author{
${ }^{1}$ Francielli Geremia, ${ }^{2}$ Lucheli Sirtoli Corá, ${ }^{3}$ Luis Gustavo Bertoldo, ${ }^{4}$ Alberto Ricardo Stefeni, ${ }^{5}$ Rayanah Stival \\ Svidzinski, ${ }^{6}$ Fernando Luiz Schneider
}

${ }^{1}$ Agronomist engineer, Teaching Union of the Southwest of Paraná (Unisep), Dois Vizinhos, PR, 85660-000, Brazil.

${ }^{2}$ Agronomist engineer, Union of the Southwest of Paraná (Unisep), Dois Vizinhos, PR, 85660-000, Brazil.

${ }^{3}$ Department of Agronomy, Federal Technological University of Paraná (UTFPR), Pato Branco, PR, 85503-390, Brazil.

${ }^{4}$ Department of Agroecosystem, Federal Technological University of Paraná (UTFPR), Dois Vizinhos, PR, 85660-000, Brazil.

${ }^{5}$ Department of Agronomy, Federal Technological University of Paraná (UTFPR), Pato Branco, PR, 85503-390, Brazil.

${ }^{6}$ Department of Agroecosystem, Federal Technological University of Paraná (UTFPR), Dois Vizinhos, PR, 85660-000, Brazil.

Correspondence Author: Francielli Geremia, Department of Agronomy, Federal Technological University of Paraná (UTFPR), Pato Branco, PR, 85503-390, Brazil.

E-mail: - Albertostefeni@yahoo.com.br

Received date: 19 June 2019, Accepted date: 26 August 2019, Online date: 29 August 2019

Copyright: (C) 2019 Francielli Geremia et al, This is an open-access article distributed under the terms of the Creative Commons Attribution License, which permits unrestricted use, distribution, and reproduction in any medium, provided the original author and source are credited.

\begin{abstract}
Beans represent one of the most traditional foods in the Brazilian diet, providing essential nutrients such as proteins, minerals, vitamins, carbohydrates and fibers, in this way the search for new technologies that promote productivity improvements is of fundamental importance. The objective of this work was to evaluate the effect of different concentrations of bio-stimulant on seed germination and initial seedling development of beans TANGARA $®$ belonging to the carioca commercial group. The experiment was conducted at the Laboratório de Tecnologia de Sementes da Faculdade Educacional de Dois vizinhos/FAED - UNISEP - União de Ensino do Sudoeste do Paraná, Campus Dois Vizinhos - PR. The experimental design was completely randomized (DIC) with 5 treatments and four replicates of 50 seeds each. The $f$ treatments consisted of different concentrations of stimulate ${ }^{\circledR}$, being: T1: control; T2: $1 \mathrm{~mL}$ of stimulate ${ }^{\circledR} / \mathrm{kg}$ of seeds; T3: $2 \mathrm{~mL}$ of stimulate $® / \mathrm{kg}$ of seeds; T4: $4 \mathrm{~mL} \mathrm{of}$ stimulate $₫ / \mathrm{kg}$ of seeds; T5: $6 \mathrm{~mL}$ of stimulate $₫ / \mathrm{kg}$ of seeds. The percentage of normal, abnormal germinated seeds, hard seeds and dead seeds, root and shoot length were evaluated. There was a positive effect for the percentage of germination of seeds and non-geminated seeds at 5 days, normal seedlings, root and shoot length at concentrations of 4 and $6 \mathrm{~mL} / 1 \mathrm{~kg}$ of bean seed.
\end{abstract}

Keywords: Phaseolus vulgaris L. seeds. Seedlings

\section{INTRODUCTION}

Brazil is one of the main world producers of beans (Phaseolus vulgaris L.), with 3,182.7 thousand tons produced in the 15/16 harvest, being one of the main foods that comprises the Brazilian basic basket (CONAB, 2016). This way contributing significantly as an important nutritional source (GONÇALVES et al., 2017).

Delimiting the federal units of Brazil, the state of Paraná is the largest national producer with 447.5 thousand hectares planted in the 16/17 harvest and 710.5 thousand tons produced (CONAB, 2017). In Brazil, beans are widely consumed, although the per capita consumption has fallen from $19 \mathrm{~kg}$ / inhabitant per year in the 90 's to $16 \mathrm{~kg} /$ inhabitant per year in the next decade, possibly because of urbanization and change process in eating habits (Wander et al., 2007).

One of the main hindrances of the agricultural exploitation of this culture is related to the high cost of production, in this way the search for new technologies that contribute to the good vegetal development and the maximization of the productivity is essential.

Thus, the use of bio-regulators has intensified in recent years, applied in diverse cultures with the purpose of improving the development of the plant, aiming to raise the levels of productivity. It is believed that the cocktail composed of indole butyric acid, kinetin and gibberellic acid, can promote plant development, improving productivity.

In this context, bio-stimulants appear, basically consisting of bio-regulators, amino acids, flavic and humic acids and seaweed, and can be applied and consequently increase the absorption and efficiency of nutrient use (GOMEZ-MERINO, TREJO-TÉLEZ, 2015). They may also contain micronutrients, zinc and molybdenum (FERREIRA, et al., 2016). 
Citation: Francielli Geremia, et al., Germination and Initial Development of Carioca Beans Treated with Bio-Stimulant. Australian Journal of Basic and Applied Sciences, 13(8): 24-28. DOI: 10.22587/ajbas.2019.13.8.4

This type of input can be used to favor some processes, such as increased cell division and stretching; chlorophyll synthesis; photosynthesis; differentiation of floral buds; fixation and size of fruits and nutrient absorption (DU JARDIN, 2015).

Among the functions of the bio-stimulants the auxins promote the formation of lateral and adventitious roots, besides being involved in the permeability of the membranes and possessing characteristic action in the cellular stretching. Cytokines regulate cell division and differentiation and gibberellins are involved in seed germination, since quiescence overcomes, as well as in hydrolysis control of reserves (TAIZ; ZEIGER, 2013).

Therefore, it is justified to perform this work due to the need of obtaining new information on the use of bio-stimulants and their effects on germination of bean seeds.

The objective of this work was to evaluate the effect of different concentrations of bio-stimulant on seed germination and initial development of bean seedlings of the TANGARA® variety, belonging to the carioca commercial group.

\section{MATERIAL AND METHODS}

The experiment was carried out in 2017 in the experimental field belonging to the União de Ensino do Sudoeste do Paraná UNISEP - Faculdade Educacional de Dois Vizinhos - FAED, situada no município de Dois vizinhos, PR, located in the Southwest region of Paraná, with latitude $25^{\circ} 45^{\prime} 00$ " and longitude of $53^{\circ} 03$ '25 " and with an altitude of 509 meters.

For the conduction of the experiment, bean seeds of the TANGARA® variety of the carioca commercial group were used, with an average cycle of 87 days, and were purchased in local commerce.

The experimental design used was completely randomized (DIC), with five treatments and four replicates of 50 seeds each, totaling 200 seeds per treatment. The treatments were constituted of different concentrations of stimulate $®$ being: T1: control; T2: $1 \mathrm{~mL} ר$ of stimulate $\AA / \mathrm{kg}$ of seeds; T3: $2 \mathrm{~mL}$ of stimulate ${ }^{\circledR} / \mathrm{kg}$ of seeds; $\mathrm{T} 4: 4 \mathrm{~mL}$ of stimulate ${ }^{\circledR} / \mathrm{kg}$ of seeds; T5: $6 \mathrm{~mL}$ of stimulate ${ }^{\circledR} / \mathrm{kg}$ of seeds.

For the implementation of the experiment the seeds previously underwent a disinfestation process with $2 \%$ hypochlorite for 5 minutes. For the application of the treatments, the product was diluted in distilled water, forming a homogeneous solution, then the seeds were immersed in the solution for a time of 30 minutes.

For sowing, germitest ${ }^{\circledR}$ paper was used, previously moistened with distilled water 2.5 times the paper weight (BRASIL, 2009). At the time of sowing care was taken to keep the seeds equidistant from each other. After the seeds were placed in the germitest ${ }^{\circledR}$ paper, they were rolled for closure and placed in a germination chamber. The germination chamber was maintained at a temperature of $25^{\circ} \mathrm{C} \pm 1$ with photoperiod of 12 hours, according to data obtained in RAS - rules of seed analysis (BRASIL, 2009).

The evaluations were performed at 5 and 9 DAS - days after sowing, counting the normal, abnormal germinated seeds, hard seeds and dead seeds as determined by RAS (BRASIL, 2009), considering the data will be transformed to a percentage. In the last assessment, Root length $(\mathrm{cm})$ size of shoot $(\mathrm{cm})$ was measured using a ruler, by measuring ten seedlings per repetition, randomly selected and the results expressed in centimeters.

The obtained data were submitted to analysis of variance (test F), and the treatments compared through the computational application SISVAR® (FERREIRA, 2000). A polynomial regression analysis was performed at a 5\% probability of error.

\section{RESULTS AND DISCUSSION}

Figure 1 shows the data related to the percentage of germinated seeds of beans evaluated at five days after sowing submitted to the treatment with different concentrations of bio-stimulant.

The statistical analysis showed significant differences, where the regression that best represented the data was polynomial, which shows that all treatments had an increase in the percentage of germination when compared to the control. When analyzing the means, it is possible to verify that the treatment in the dose of $6 \mathrm{~mL} \mathrm{~kg}^{-1}$ of seed showed the highest germination of bean seeds in this evaluation. The tendency of the equation shows that the concentrations of 2 and $1 \mathrm{~mL} \mathrm{~kg}^{-1}$ of seed provided the lowest percentage of germination of bean seeds in relation to the other two concentrations used.

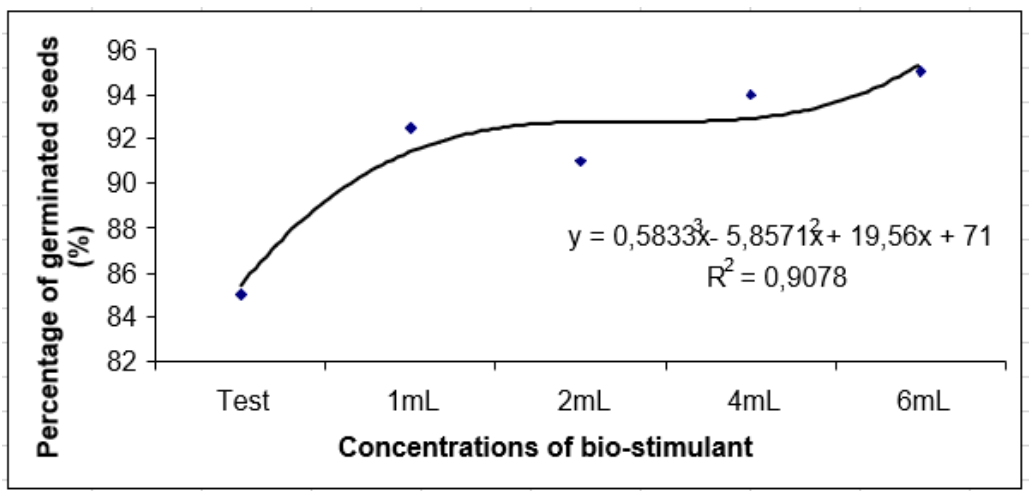

Figure 1: Percentage of germinated seeds of beans of the TANGARA® variety belonging to the carioca commercial group, evaluated at five days after sowing submitted to treatments with different concentrations of bio-stimulant. Dois Vizinhos-PR, 2017. 
In this case, it is suggested that the phytohormones present in the bio-stimulant promoted the increase of the vigor obtained in the first count of germination, as a result of its actions in the division and cellular stretching.

Passion fruit seeds showed a significant increase in the percentage of emergence when treated with auxin-based bio-stimulant + gibberellin + cytokinins at concentrations of 12 and $16 \mathrm{~mL} \mathrm{~kg}^{-1}$ of seed (FERREIRA et al., 2007).

Aragão et al. (2001) verified a favorable effect of the $\mathrm{GA}_{3}$ regulator on the speed and percentage of germination, with consequent reflection on the quality of the corn seedlings.

As for the percentage of non geminated seeds (Figure 2), there were significant statistical differences where the regression that best represented the data was the linear regression, that is to say there was a decrease in the percentage of non-germinated seeds as there was an increase in the concentrations of the bio-stimulant.

All concentrations of the bio-stimulant provided a lower percentage of non-germinated seeds compared to witness. When comparing the averages, it was observed that the treatments in the concentrations of 1 and $4 \mathrm{~mL} \mathrm{~kg}^{-1}$ were the ones that provided the lowest percentage of non-germinated seeds.

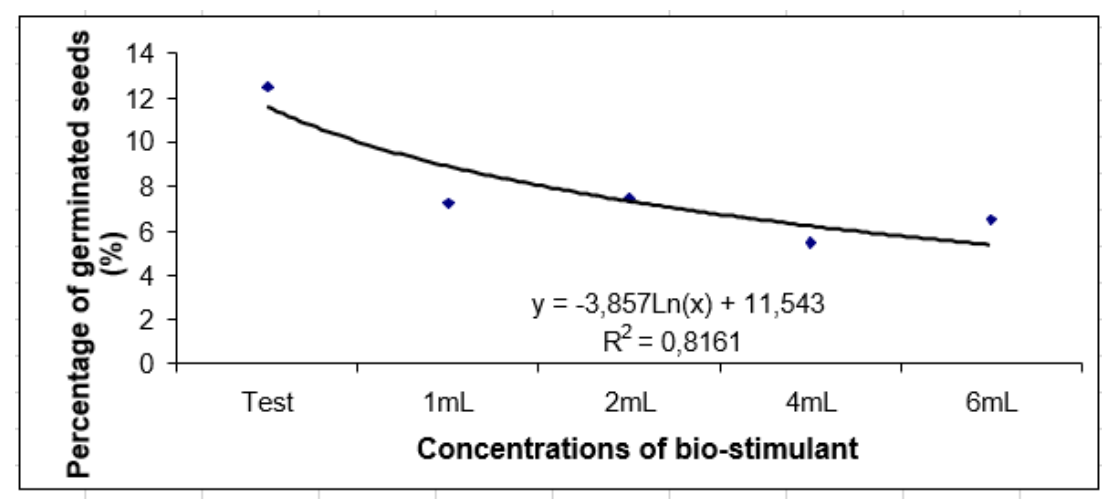

Figure 2: Percentage of non-germinated seeds of TANGARA ${ }^{\circledR}$ variety beans, belonging to the carioca commercial group as evaluated at five days after sowing, subjected to treatment with different concentrations of bio-stimulant. Dois Vizinhos-PR, 2017.

In (Figure 3) the normal seedlings percentage, statistical and significant differences between treatments were observed, where regression that best adapted was the quadratic. There was an increase in the percentage of normal seedlings in all the treatments used when compared to the control. Treatments at concentrations of 4- and $6-\mathrm{mL} \mathrm{kg}^{-1}$ of seed provided the largest increase in the number of normal seedlings. Treatment with the dose of $2 \mathrm{mLkg}^{-1}$ of seed showed the lowest percentage of normal seedlings among all the concentrations, including the treatment at the lowest dose $\left(1 \mathrm{~mL} \mathrm{~kg}^{-1}\right)$ of seed, which is not clear the efficacy of the product in lower concentrations.

There are several studies with the use of bio-stimulants in seeds of several crops, and the most promising results are related to higher concentrations of bio-stimulant, which corroborates the results of this work.

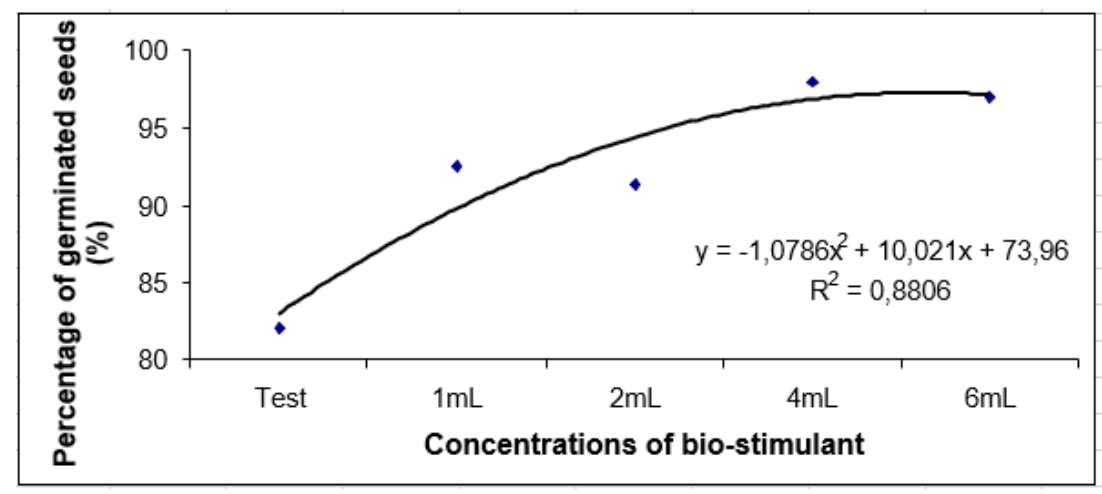

Figure 3: Percentage of normal seedlings of the TANGARA® bean variety, belonging to the carioca commercial group, evaluated at nine days after sowing that were subjected to treatment with different concentrations of bio-stimulant. Dois Vizinhos-PR, 2017.

Vieira; Castro (2001) obtained bio-stimulating effects on the germination of soybean seeds (cv. IAC-8-2), when they found out that the concentration of $3.5 \mathrm{~mL}$ per $0.5 \mathrm{~kg}^{-1}$ of bio-stimulant seeds gave the maximum number of normal seedlings, with an increase of $51.9 \%$ in relation to the control.

For the percentage of normal and deteriorated seedlings (Table 1), there were not statistical and significant differences between the treatments of both variables analyzed.

Seedlings correspond to a very delicate stage of the plant life cycle, and initial growth and survival may be directly related to the nutritional reserves present in the seed, which are essential for the formation of normal seedlings. 
Table 1. Percentage of normal and deteriorated seedlings of the TANGARA ${ }^{\circledR}$ bean variety, belonging to the carioca commercial group, evaluated at nine days after sowing, subjected to treatment with different concentrations of bio-stimulant. Dois Vizinhos-PR, 2017.

\begin{tabular}{|c|c|c|}
\hline Concentrations & Abnormal (\%) & Deteriorated (\%) \\
\hline Control & $3,50^{\mathrm{ns}}$ & $3,50^{\mathrm{ns}}$ \\
\hline $1 \mathrm{Ml}$ & 0.00 & 0.00 \\
\hline $2 \mathrm{~mL}$ & 3.50 & 0.50 \\
\hline $4 \mathrm{~mL}$ & 0.00 & 0.00 \\
\hline $6 \mathrm{~mL}$ & 0.50 & 0.00 \\
\hline $\mathrm{CV}$ & 34.36 & 37.69 \\
\hline
\end{tabular}

Non-significant by the "F" test.

As for the root length (Figure 4), we can observe significant statistical differences between the treatments where the regression that best adapted was the polynomial one. There was an increase in the percentage of normal seedlings in all the treatments used when compared to the control. The treatments at the concentrations of 4- and 6- $\mathrm{mL} \mathrm{kg}^{-1}$ of seeds were the ones that provided the highest root length.

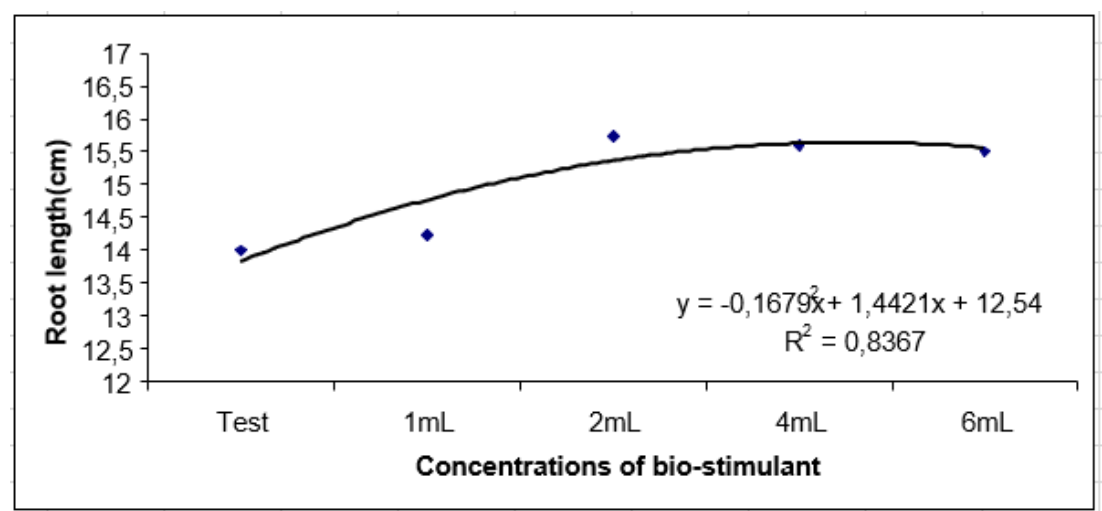

Figure 4: Root length of bean seedlings of the TANGARA ${ }^{\circledR}$ bean variety, belonging to the carioca commercial group, evaluated at nine days after sowing, subjected to treatment with different concentrations are bio-stimulant. Dois Vizinhos-PR, 2017.

The treatment at the dose of $1 \mathrm{~mL} \mathrm{~kg}^{-1}$ of seed provided the lowest root length, and their results were similar to that of the control treatment. The same treatment had shown discrepant results to germinated seeds (Figure 1) evaluated at five days and for normal seedlings now and again for root length, therefore it can be said that there may have been some interference even in the photoperiod, as a consequence of the positioning in the germination chamber or the quantity of water, either in excess or lack, since the data differs largely from the other treatments. Vieira (2005). Testing cotton seeds treated with bio-stimulant, they had a $45.5 \%$ increase in seedling root length, using a dose of $17.4 \mathrm{~mL}$ of Stimulate ${ }^{\circledR}$ per $0.5 \mathrm{~kg}$ of seeds. Corroborating with the results of this work, the bio-stimulant used in the highest concentrations provided increases in root length, but in a lower percentage. Perhaps if larger concentrations of the bio-stimulant were used it would be possible to obtain larger percentages of increment in the root length.

Increases in the length of the primary and shoot length of some cultivars, may confirm some effect of the bio-regulator as a stimulator of cell division, cell differentiation and elongation, and may increase the uptake and use of water and nutrients by plants (STOLLER DO BRASIL, 1998). The variable of the shoot length (figure 5) showed statistically significant differences between the treatments where the regression that best adapted was linear, that is, there was an increase in the length of the shoot length as the increase of the concentrations of bio-stimulant.

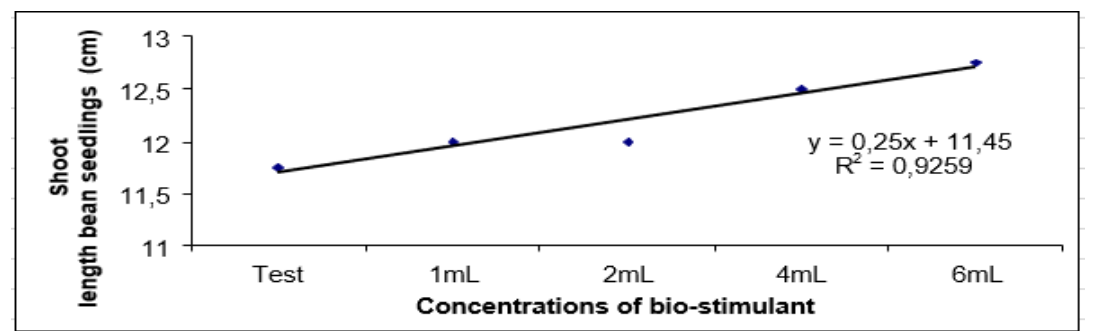

Figure 5: Shoot length bean seedlings of the of the TANGARA ${ }^{\circledR}$ bean variety, belonging to the carioca commercial group, evaluated at nine days after sowing, subjected to treatment with different concentrations are biostimulant. Dois Vizinhos - PR, 2017.

Gomes; Martin-Didonet (2003), evaluated the effect of Stimulate ${ }^{\circledR}$ and inoculation with Azospirillum brasilense on bean seeds and verified a positive effects of the bio-stimulant on the Valente cultivar for the variable length of the shoot length, main 
Citation: Francielli Geremia, et al., Germination and Initial Development of Carioca Beans Treated with Bio-Stimulant. Australian Journal of Basic and Applied Sciences, 13(8): 24-28. DOI: 10.22587/ajbas.2019.13.8.4

root, number of roots, root volume and fresh and dry mass of aerial part and root. Santos et al. (2013) verified a 32.7\% and $22.0 \%$ increase in the seedling shoot growth in relation to the control when they used bio-stimulant concentrations in pre-soaked sunflower seeds for 4 and 10 hours, respectively.

\section{CONCLUSIONS}

There was a positive effect for the percentage of seed germination and non-germinated seeds at 5 days, normal seedlings, root and shoot length at concentrations of 4 and $6 \mathrm{~mL} / 1 \mathrm{~kg}$ of bean seeds.

However, there is a need for new work with higher bio-stimulant concentrations than those used in this experiment.

\section{FUTURE WORKS}

To evaluate in the field the yield components of the bean culture submitted to different concentrations of bio-stimulant associated with the use of Bradyrizobium and A. brasiliense bacterias.

\section{REFERENCES}

ARAGÃO CA, LIMA MWP, MORAIS OM, ONO EO, BOARO CSF,RODRIGUES JD, NAKAGAWA J; CAVARIANI C. Fitorreguladores na germinação de sementes e no vigor de plântulas de milho super doce. Revista Brasileira de Sementes, 23:62-67. 2001.

CONAB. Perspectivas para a agropecuária. Volume 5 - Safra 2017/2018. Produtos de Verão.

BRASIL. Ministério da Agricultura e Reforma Agrária. Regras para análise de sementes. Brasília: SNDA/DNDV/CLAV, p. 365. 2009.

DU Jardin P. Plant biostimulants: Definition, concept, main categories and regulation. Scientia Horticulturae, 2015; 196(1): 3-14,doi:10.1016/j.scienta.2015.09.021

FERREIRA, D.F. Análises estatísticas por meio do Sisvar para Windows versão 4.0. In... REUNIÃO ANUAL DA REGIÃO BRASILEIRA DA SOCIEDADE INTERNACIONAL DE BIOMETRIA, 45, 2000. Anais... São Carlos, SP: SIB, p. 255-258, 2000.

FERREIRA BONTEMPO, A.M.; ALVES, F L; DAIER OLIVEIRA, G.A.B.; GONÇALVES MACHADO, L.U.; OTÁVIO DUARTE SILVA, L.U. Influência de bioestimulantes e nutrientes na emergência e no crescimento inicial de feijão, soja e milho. Revista Brasileira de Milho e Sorgo, v. 15, n. 1, p. 86-93, 2016.

GÓMEZ-MERINO, F.C.; TREJO-TÉLLEZ, L.I. Biostimulant activity of phosphite in horticulturae. Scientia Horticulturae, 2015; 196(1): 82-90, doi:10.1016/j.scienta.2015.09.035.

GONÇALVES, J. A. et al. "Eficiência relativa da adubação com fósforo polimerizado na cultura do feijoeiro irrigado." Anais do Congresso de Ensino, Pesquisa e Extensão da UEG, vol. 3. 2017.

SANTOS, C. A. C. et al. Stimulate na germinação de sementes emergência e vigor de plântulas de girassol. Bioscience Journal, Uberlândia, v. 29, n. 2, p. 605-616, 2013.

SANTOS, M. P.; VALE, L. S. R.; REGES, N. P. R.; CARVALHO, B. M. Desempenho de sementes de quatro cultivares de feijão (Phaseolus vulgaris) na microregião de Ceres-GO Global Science and Technology, v. 8, n. 3, 2016.

STOLLER DO BRASIL (1998) Stimulate Mo em hortaliças: Informativo técnico. Cosmópolis, Stoller do Brasil. 1p.

TAIZ, L.; ZEIGER, E. Fisiologia vegetal. 5. ed. Porto Alegre: Artmed, p. 954. 2013.

VIEIRA E. L; MARTINS MC; SPINOLA M. C. M; CASTRO P. R.C (2001) Estudos preliminares da ação de Stimulate e inoculante na qualidade fisiológica de sementes e no desenvolvimento inicial do sistema radicular de plantas de Glycine max L. (Merrill). In: XII Congresso Brasileiro de Sementes, Curitiba. Resumos, Informativo ABRATES. P.65-65.

VIEIRA E. L (2005) Stimulate 10 X na germinação de sementes, vigor de plântulas e crescimento inicial de plantas de algodoeiro. In: V Congresso Brasileiro de Algodão, Salvador. Anais. Embrapa Algodão. P.163-163.

WANDER, A. E.; et al. Evolução da produção e do mercado mundial do feijão. XLV Congresso da SOBER: Conhecimento para Agricultura do Futuro, p. 4-8, 2007. AGROFIT, Ministério da Agricultura, Pecuária e Abastecimento. Disponível em: <http://agrofit.agricultura.gov.br/agrofit_cons/principal_agrofit_cons> Acesso em: 12 de mar. 2017. 